\title{
Reviews of UK university research 'have helped to raise standards'
}

London. Efforts over several years to concentrate support for research in British universities on those institutions that demonstrate that they are able to use it effectively appear to be bearing fruit, according to the funding councils that distribute government money to them.

The conclusions are based on the fourth research assessment exercise of British universities, the results of which were published in London shortly before Christmas by the Higher Education Funding Council for England. The previous exercises were carried out in 1986, 1989 and 1992, and funding council officials say that the latest round reveals a significant increase in the overall quality of research compared to 1992.

Using a complex and highly codified set of assessment techniques, each department in each university was reviewed by a panel of specialists in the field and given a rating of between 1 and 5, with the third level being split into $3 \mathrm{a}$ and $3 \mathrm{~b}$, and outstanding departments receiving a $5^{*}$ mark.

The marks will now be used by the three separate funding councils (covering England, Scotland and Wales respectively), as well as the Department of Education for Northern Ireland, in allocating government funding to institutions for next year. Those given a 1 or 2 rating will not receive any government support for their research (although they can use funds received from elsewhere for this). Those allocated $5^{*}$ can expect to see continued generous backing.

Perhaps inevitably, not all the marks have been well-received, particularly by departments that feel their research strengths have been underestimated. David Southwood, for example, head of the physics department at Imperial College, London, which was awarded a 5 - but not a $5^{*}$, which only went to the departments at Oxford and Cambridge - claimed that insufficient recognition had been given to the breadth and "cohesiveness" of work in his department.

There was deeper anger at the University of Lancaster that their department, which has the highest 'impact factor' of any English physics department as measured by the Institute for Scientific Information in Philadelphia, only received a 3 a rating. Peter McClintock, professor of physics, asks: "Why should a department that, averaged over all its staff, is demonstrably England's star performer in international physics have been treated in this shameful way?"

Conversely, the high scores won by some university departments have been looked at slightly sceptically by those at other universi- ties, who claim that the results may reflect carefully honed submissions rather than quality in depth (universities were allowed to choose which researchers in a particular department to enter).

The final conclusions also gave rise to some public disputes about their interpretation. Both the universities of Oxford and Cambridge claimed to have come top of the list, the first using as an indicator the average score for all the researchers whose work it submitted for review, the second a different score based on all its academic staff.

Overall, however, the level of complaints has been relatively low. "I don't know of any case where a department's score has been more than one grade higher or lower than had been expected," says one biologist.

The results have been a welcome boost to some of the so-called 'new universities', which were called polytechnics until the beginning of the 1990s and are struggling to build reputations in research. Nottingham Trent University - previously Trent Polytechnic - for example, saw 82 per cent of its research-active staff rated in $3 a$ or $3 b$ departments.

"I am delighted with our result," says Richard Joyner, the university's director of research. "It shows that in the new university sector there is a will to develop and manage research effectively."

Brian Fender, former vice-chancellor of the University of Keele, emphasizes that the overall number of university departments receiving a $3 a$ or $3 b$ rating - each equivalent to a level of 'national excellence' - rose from 589 in 1992 to 716 in 1996, with an increase from 96 to 351 among the former polytechnics alone.

"The real winner in all this appears to be the United Kingdom, which is benefiting from a huge range of high quality work," says Fender. While the best universities have improved their international standing those receiving grades 5 and $5^{*}$, indicating an international level of excellence, rose from 308 to 497 — "many other institutions have performed impressively by identifying and building on their strengths," he says.

Fender also counters claims that some universities have been seeking to increase their scores by selectively recruiting talented individuals at inflated salaries, often referred to as the 'transfer market' by analogy with the activities of professional soccer clubs. He claims that the impact of the transfer market appears to be 'minimal', although anecdotal evidence from many university departments suggests that it remains significant in certain cases.

The assessment results have been welcomed by the lobby group Save British Science. "The exercise shows that we have a substantial asset in our science base," says John Mulvey, the group's secretary. "That is not an excuse for saying that we do not need more money; but it does confirm that, with a bit of extra funding, Britain could become the laboratory of Europe."

\section{Austria bans gene-modified maize}

London. The Austrian government imposed a national ban last week on imports of genetically modified maize from the United States, despite a previous decision by the European Commission (EC) in Brussels to allow the grain to be sold within the European Union (EU).

Two weeks ago, Ritt Bjerregaard, the EC's environment commissioner, accepted the judgement of three of the commission's scientific committees, which concluded that the maize does not pose a threat to human or animal health. But Christa Krammer, Austria's health minister, then announced that Austria would not allow imports of modified maize, claiming to be unconvinced by statements about its safety.

The minister said that the effect of inserting a marker gene resistant to the antibiotic ampicillin has not been properly evaluated. The maize is also modified to produce a toxin that kills the European corn borer pest, and contains a gene conferring resistance to a herbicide.

The EC decision will satisfy companies, such as Ciba Geigy, which had been prevented from exporting maize to the EU after it had emerged that they intended to sell unsegregated consignments of genetically modified and unmodified grain. Bjerregaard is reported to have promised to revise a directive in which labelling is required only for food that carries specific risks, and Ciba Geigy to have promised to label its bags of modified maize.

Ehsan Masood 